\title{
Electrochemical Selective Leaching and Deposition of Ag, Au and $P t$ from electronic waste
}

\author{
C. Cortés López ${ }^{1}$, V. E. Reyes Cruz ${ }^{1, *}$, M. A. Veloz Rodríguez ${ }^{1}$, G. Urbano Reyes ${ }^{1}$, J.A. Cobos Murcia ${ }^{1,}$ \\ ${ }^{2}$, J.L. Nava Montes de Oca ${ }^{3}$ \\ 1 Área Académica de Ciencias de la Tierra y Materiales, Universidad Autónoma del Estado de \\ Hidalgo, Carr. Pachuca-Tulancingo km 4.5 C.P.42184, Tel: 7172000 ext.2279, México. \\ ${ }^{2}$ Consejo Nacional de Ciencia y Tecnología, Depto. de Cátedras, Av. Insurgentes Sur 1582, Col. \\ Crédito Constructor, Delegación Benito Juárez, México D.F., C.P. 03940. \\ ${ }^{3}$ Depto. de Ingeniería de Hidráulica y Geomática, UG, Av. Juárez 77, Zona Centro, Guanajuato, Gto., \\ México. \\ *E-mail: reyescruz16@yahoo.com.mx
}

doi: $10.20964 / 2017.09 .45$

Received: 23 March 2017 / Accepted: 8 July 2017 / Published: 12 August 2017

In this work, selective electrochemical leaching of compact anodes, made from electronic waste (ewaste) powder containing metals such as silver $(\mathrm{Ag})$, gold $(\mathrm{Au})$ and platinum $(\mathrm{Pt})$, was studied in presence of copper $(\mathrm{Cu})$, nickel $(\mathrm{Ni})$, Tin $(\mathrm{Sn})$ and zinc $(\mathrm{Zn})$, as well as metal selective deposition from solutions generated during electrochemical leaching. Thermodynamic analysis, potentiodynamic polarization and potentiostatic techniques were used to establish the conditions that promote selective leaching and deposit of $\mathrm{Ag}, \mathrm{Au}$ and $\mathrm{Pt}$ in $10 \% \mathrm{HNO}_{3}$. X-ray diffraction (XRD), scanning electron microscopy (SEM) and inductively coupled plasma (ICP) spectroscopy were used to validate the results. Findings showed that selective electrochemical leaching for precious metals (Ag, $\mathrm{Au}$ and $\mathrm{Pt}$ ) was possible at potential ranges between 1.1 to $1.17 \mathrm{~V}$ vs. SCE. Leaching was favored by the formation of metallic oxides (i.e., $\mathrm{NiO}_{2}, \mathrm{Cu}_{2} \mathrm{O}$ and $\mathrm{SnO}$ ), which limits the leaching of interfering elements that are present in high concentrations in the e-waste, such as $\mathrm{Cu}$. It is also indicated that four regions of deposit were found using the leaching solution from e-waste, where selectivity zones of precious metals deposit was found in region I (from $-0.2 \mathrm{~V}$ to $-0.21 \mathrm{~V}$ vs. SCE) and region II (at $-0.25 \mathrm{~V}$ vs. SCE). While region III and IV (above $-0.3 \mathrm{~V}$ ), copper is the predominant species that produces more uniform and shining deposits.

Keywords: Electrochemical leaching, selective deposit, e-waste, $\mathrm{Pt}, \mathrm{Au}, \mathrm{Ag}$ and $\mathrm{Cu}$. 
(C) 2017 The Authors. Published by ESG (www.electrochemsci.org). This article is an open access article distributed under the terms and conditions of the Creative Commons Attribution license (http://creativecommons.org/licenses/by/4.0/). 